\title{
PKM KELOMPOK BUDIDAYA JAMUR SAKINAH DAN PKK DESA PINANG LUAR KECAMATAN KUBU, KABUPATEN KUBU RAYA, KALIMANTAN BARAT
}

\author{
Elliska Murni Harfinda ${ }^{1)}$, Nizarrahmadi ${ }^{2)}$, Sigit Normagiat ${ }^{3)}$, \\ Rista Delyani ${ }^{4)}$, Reza Wahyudi ${ }^{5}$, Mahyarudin') \\ ${ }^{1,3,4)}$ Fakultas Pertanian, Universitas Nahdlatul Ulama Kalimantan Barat \\ ${ }^{2)}$ Fakultas Keguruan dan Ilmu Pendidikan, Universitas Nahdlatul Ulama Kalimantan Barat \\ ${ }^{5)}$ Fakultas Teknik, Universitas Nahdlatul Ulama Kalimantan Barat \\ ${ }^{6)}$ Fakultas Kedokteran, Universitas Tanjungpura \\ *email: elliskamurniharfinda@unukalbar.ac.id
}

\begin{abstract}
Abstrak
Berdasarkan diskusi pada kegiatan orientasi lapang dengan Kelompok Budidaya Jamur Sakinah, terdapat keluhan mengenai sulitnya memperoleh baglog untuk media pertumbuhan jamur tiram. Padahal, di sekitar Desa Pinang Luar terdapat banyak sawmill mini yang menghasilkan limbah serbuk gergaji yang merupakan bahan utama pembuatan baglog jamur. Selain itu, kami juga bertemu dengan anggota PKK Desa Pinang Luar. Selama ini, para ibu rumah tangga yang merupakan anggota PKK masih melakukan usaha budidaya hortikultura konvensional yang dikelola di lahan sekitar pekarangan rumah. Budidaya dengan cara seperti ini mereka akui tidak mendapatkan hasil yang maksimal. Oleh karena itu, Tim PKM Universitas Nahdlatul Ulama Kalimantan Barat mencoba bermitra dengan kedua kelompok tersebut dan memberikan solusi berupa Program Pembinaan Budidaya Hortikultura secara Hidroponik dan Budidaya Jamur Tiram. Target luaran yang diharapkan dapat meningkatkan keterampilan anggota kelompok dalam membudidayakan hortikultura hidroponik dan jamur tiram sehingga dapat meningkatkan pendapatan keluarga.
\end{abstract}

Kata Kunci : budidaya, desa pinang luar, hidroponik, jamur tiram

\section{PENDAHULUAN}

Desa Pinang Luar terletak di Kecamatan Kubu, Kabupaten Kubu Raya, Provinsi Kalimantan Barat. Jarak antara Ibukota Provinsi ke Desa Pinang Luar sejauh $30 \mathrm{~km}$. Sedangkan dari Ibukota Kabupaten Kubu Raya sejauh $20 \mathrm{~km}$. Perjalanan dapat ditempuh melalui jalan darat dan air selama kurang lebih 1 jam dari Kota Pontianak. Desa Pinang Luar penduduknya mayoritas bermatapencaharian sebagai petani. Namun, sekarang mata pencaharian utama kepala keluarga beralih ke perkebunan sawit. Hal tersebut menyebabkan pendapatan masyarakat tergantung pada besaran gaji yang diberikan oleh perusahaan sawit. Banyak lahan yang pada mulanya digunakan untuk budidaya tanaman pangan dan hortikultura beralih fungsi menjadi lahan perkebunan sawit. Ibu rumah tangga banyak mengeluh karena kebutuhan pangan seperti beras, jagung, umbi-umbian, sayur-mayur yang dulunya bisa dipenuhi dari lahan perladangan kini harus didapatkan dengan cara membeli. Tantangan ini harus disiasati para ibu rumah tangga melalui usaha budidaya dengan teknik rekayasa budidaya memanfaatkan lahan-lahan sempit di sekitar rumah mereka.

Kami bertemu dengan Kelompok Budidaya Jamur Sakinah yang mengeluhkan sulitnya memperoleh baglog untuk media pertumbuhan jamur tiram. Padahal, di sekitar Desa Pinang Luar terdapat banyak sawmill mini yang menghasilkan limbah serbuk gergaji yang merupakan bahan utama pembuatan baglog jamur. Mereka selama ini mendapatkan baglog dengan cara membeli dari pembudidaya lain yang lokasinya jauh dan membutuhkan biaya transportasi yang besar. Dengan membuat baglog sendiri maka biaya produksi jamur dapat ditekan.

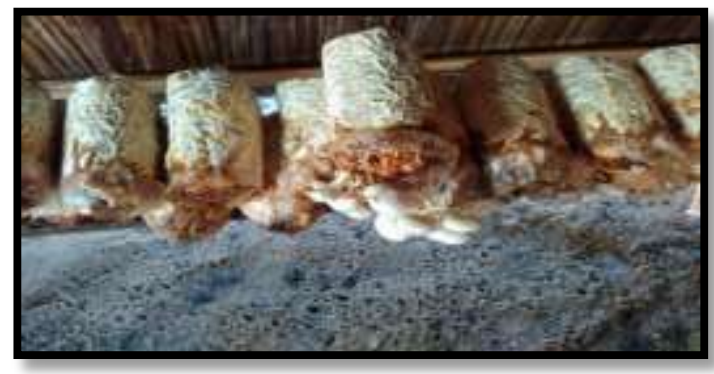

Gambar 1

Baglog yang telah selesai masa produksinya 
Berdasarkan diskusi pada kegiatan orientasi lapang, para ibu rumah tangga selama ini masih melakukan usaha budidaya hortikultura konvensional yang dikelola di lahan sekitar pekarangan rumah. Budidaya dengan cara seperti ini mereka akui tidak mendapatkan hasil yang maksimal. Masyarakat menginginkan adanya usaha sampingan berupa budidaya hortikultura dengan sistem hidroponik. Tujuannya agar hasilnya dapat dikonsumsi sendiri dan dapat dikembangkan sehingga memperoleh laba usaha. Akan tetapi, pengetahuan dan keterampilan mereka dalam praktik sistem hidroponik masih sangat minim. Bimbingan dalam penerapan sistem hidroponik dan sarana pendukungnya sangat dibutuhkan oleh warga masyarakat khususnya ibu-ibu rumah tangga di Desa Pinang Luar.

Berdasarkan hasil diskusi dengan mitra maka teridentifikasi beberapa permasalahan terkait dengan pengembangan usaha yang dilakukan oleh Kelompok Budidaya Jamur Sakinah Desa Pinang Luar dan Kelompok PKK Desa Pinang Luar, diantaranya:

a. Mitra Kelompok Budidaya Jamur Sakinah

1. Selama usaha berjalan, mitra mendapatkan baglog dengan cara membeli dan anggota kelompok belum memiliki keterampilan dalam membuat baglog sendiri

2. Sarana penunjang pembuatan baglog belum ada

3. Kurangnya kontrol pada perawatan dan pasca panen jamur

b. Mitra PKK Desa Pinang Luar

1. Kurangnya pengetahuan dan ketarampilan dalam mengelola budidaya hortikultura secara hidroponik.

2. Belum tersedianya sarana budidaya hortikultura secara hidroponik

3. Belum adanya standar kontrol dalam menjalan sistem budidaya hortikultura hidroponik

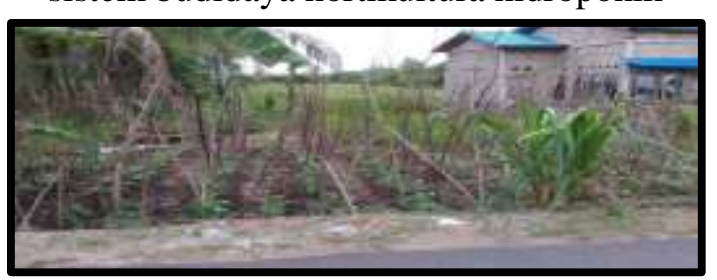

Gambar 2

Budidaya tanaman hortikultura secara konvensional dengan memanfaatkan lahan yang berada di sisi jalan

\section{METODE KEGIATAN}

Metode pelaksanaan yang dilakukan adalah dengan mengajak anggota mitra untuk bersamasama melakukan seluruh rangkaian kegiatan, memfasilitasi bahan dan alat yang diperlukan, memberikan pelatihan dan demonstrasi kepada anggota mitra, serta mempraktikkannya. Pada saat orientasi lapangan, Tim PKM melakukan perizinan pelaksanaan kegiatan. Selanjutnya, Tim PKM berkoordinasi dengan tim ahli untuk memfasilitasi autoklaf, enkas, dan instalasi hidroponik. Pelatihan budidaya hidroponik dilakukan dengan memberikan materi tentang penyemaian bibit yang dilanjutkan dengan demonstrasi penyemaian bibit serta pemasangan instalasi hirdoponik. Sedangkan pelatihan pembuatan baglog diawali dengan memberikan materi tentang komposisi baglog kemudian dilanjutkan dengan pengemasan baglog dan pengukusannya yang disertai dengan penjelasan penggunaan autoklaf. Selanjutnya, mempraktikkan penggunaan enkas disertai dengan penanaman bibit F2 ke dalam baglog yang telah dikukus. Pemantauan dilakukan pada tahap akhir dari seluruh rangkaian kegiatan untuk memastikan penggunaan fasilitas bahan dan alat yang diserahkan.

\section{HASIL DAN PEMBAHASAN}

Program Kemitraan Masyarakat (PKM) yang dilaksanakan di Desa Pinang Luar Kecamatan Kubu Kabupaten Kubu Raya, Kalimantan Barat terdiri dari dua kegiatan yang berbeda. Pertama, kegiatan pembuatan baglog pada Kelompok Budidaya Jamur Sakinah. Kedua, kegiatan budidaya hortikultura secara hidroponik pada PKK Desa Pinang Luar. Tujuan dari kegiatan PKM ini adalah untuk meningkatkan keterampilan masing-masing anggota kelompok sesuai bidangnya.

Pelaksanaan PKM diawali dengan orientasi lapang untuk menentukan waktu dan tanggal pelaksanaan pelatihan penyemaian bibit dan pembuatan instalasi hidroponik serta pelatihan pembuatan baglog dan penggunaan autoklaf dan enkas sederhana. Selanjutnya, Tim Pelaksana memfasilitasi peralatan yang diperlukan oleh mitra yaitu autoklaf, enkas, dan instalasi hidroponik yang dibantu oleh tim ahli. 
a.

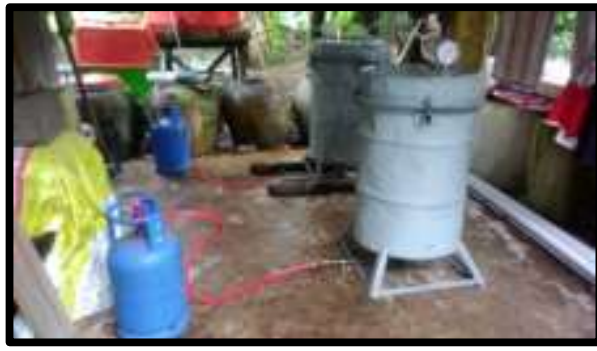

b.

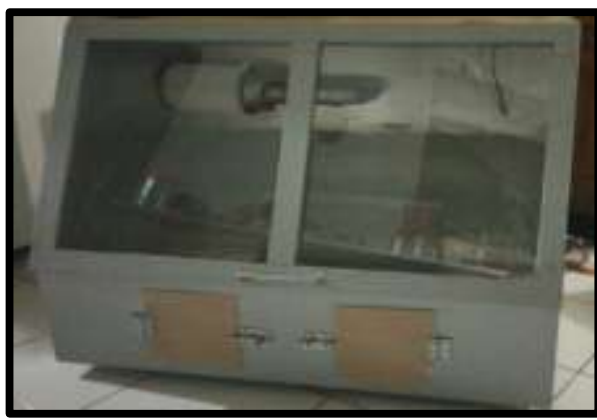

c.

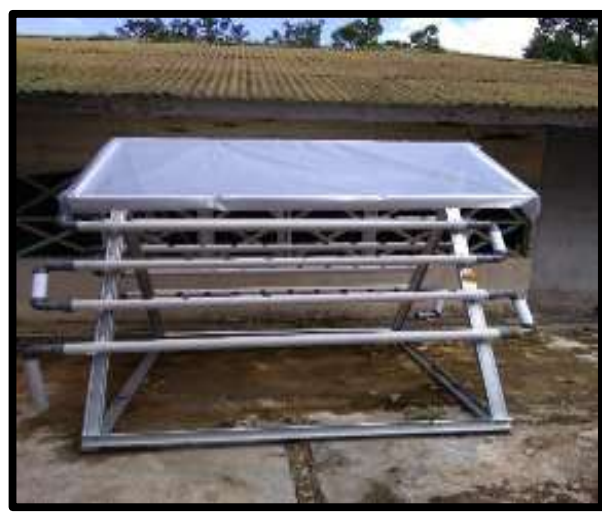

Gambar 3

Fasilitas (a) autoklaf, (b) enkas,

dan (c) instalasi hidroponik di Kelompok Mitra

Tahapan PKM berikutnya adalah memberikan pelatihan dan demonstrasi kepada anggota mitra. Pelatihan pertama melibatkan anggota PKK Desa Pinang Luar. Pelatihan penyemaian bibit dan pembuatan instalasi hidroponik dilaksanakan di Balai Desa Pinang Luar yang dihadiri oleh 28 orang anggota. Kegiatan pelatihan dibagi menjadi beberapa bagian. Bagian pertama berupa pemaparan tentang pengenalan hidroponik, media tanam, metode hidroponik, nutrisi hidroponik, dan penyemaian bibit oleh pemateri. Bagian kedua berupa praktik penyemaian bibit. Praktik yang dilakukan sebelum penyemaian bibit adalah hidroponik dengan metode Wick (sumbu) dimana peserta dibagi menjadi 2 kelompok dan diberikan botol kemasan air minum. Masing-masing kelompok didampingi untuk pembuatan Wick. Selanjutnya praktik penyemaian bibit dengan menggunakan rockwool. Masing-masing kelompok diberikan rockwool, gergaji besi, nampan, dan bibit. Rockwool dipotong dengan ukuran $2 \times 2 \mathrm{~cm}$ kemudian dilubangi tengahnya dan disiram air untuk selanjutnya dimasukkan bibit sayuran 1 buah per lubang. Selanjutnya praktik pelarutan nutrisi. Nutrisi hidroponik yang lazim digunakan adalah nutrisi $A B$ Mix. Dipraktikkan pula bagaimana cara pelarutan nutrisi dan dosis penggunaannya. Pelarutan nutrisi haruslah melihat tabel kebutuhan nutrisi masingmasing sayuran karena kebutuhan nutrisinya berbeda. Oleh karena itu, cara penggunaan TDSmeter juga dipraktikkan. Penggunaan $\mathrm{pH}$-meter juga dipraktikkan untuk mengetahui tingkat keasaman air yang digunakan karena kebanyakan masyarakat Desa Pinang Luar menggunakan air tanah yang telah diberi koagulan seperti tawas dan PAC.

a.

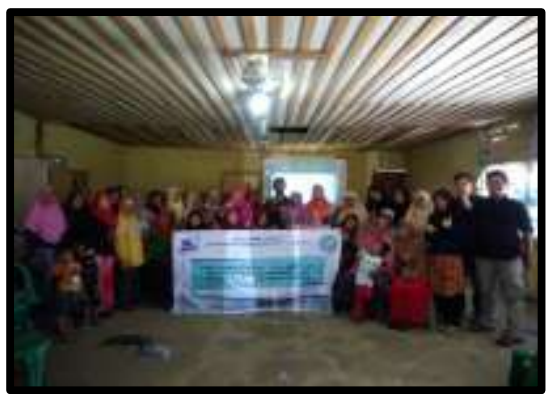

b.

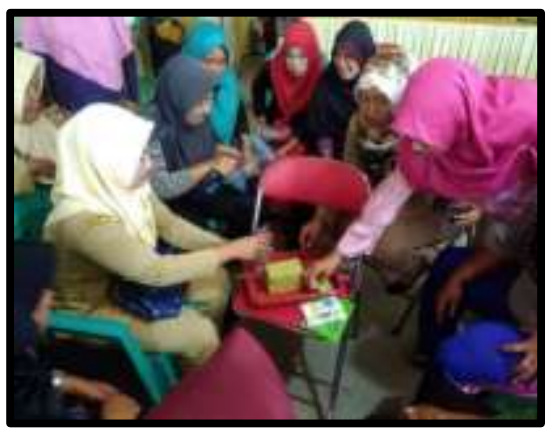

c.

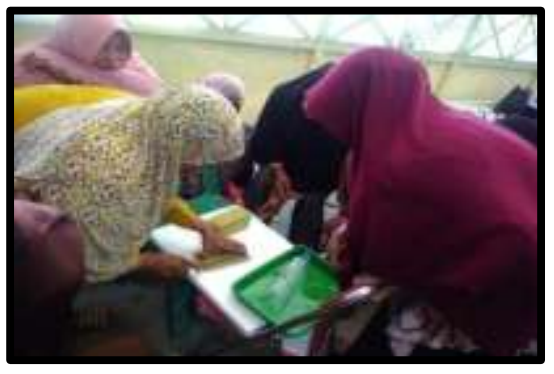

Gambar 4

Pelatihan dan demonstrasi kegiatan hidroponik pada anggota PKK Desa Pinang Luar 
Pelatihan kedua melibatkan anggota Kelompok Budidaya Jamur Sakinah. Pelatihan pembuatan baglog, penggunaan autoklaf dan enkas dilakukan di Rumah Ketua Kelompok Budidaya Jamur Sakinah. Hal ini dilakukan karena kumbung budidaya jamur tiram terletak disana. Pelatihan ini dihadiri oleh 20 orang anggota. Kegiatan pelatihan dibagi menjadi tiga bagian dalam tiga hari. Bagian pertama pada hari pertama berupa penyampaian materi tentang komposisi baglog yang terdiri dari serbuk gergaji, dedak, dan kapur. Pada bagian ini, peserta pelatihan mempraktikkan secara langsung pembuatan media tanam dan penambahan air hingga diperoleh komposisi air pada media tanam yang tepat. Bagian kedua pada hari kedua berupa penyampaian materi dan praktik tentang pengisian dan packing baglog serta pengukusan baglog menggunakan autoklaf yang dilakukan selama 8 jam. Bagian ketiga pada hari ketiga berupa penyampaian materi dan praktik tentang penanaman bibit F2 jamur tiram ke dalam baglog menggunakan enkas. Disampaikan pula cara menggunakan enkas dalam keadaan steril untuk meminimalisir terjadinya kontaminasi.

a.

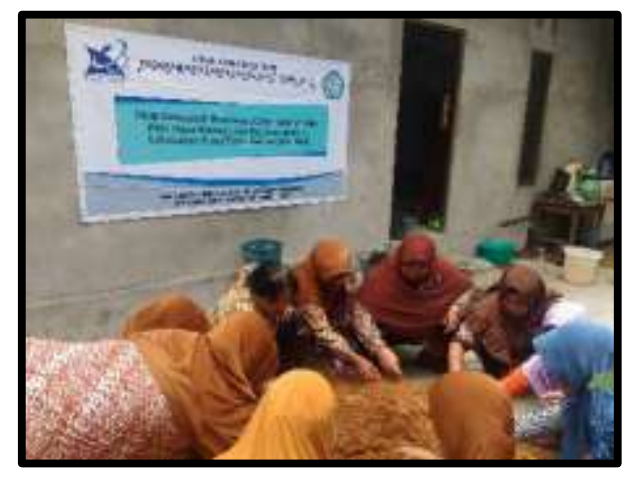

b.

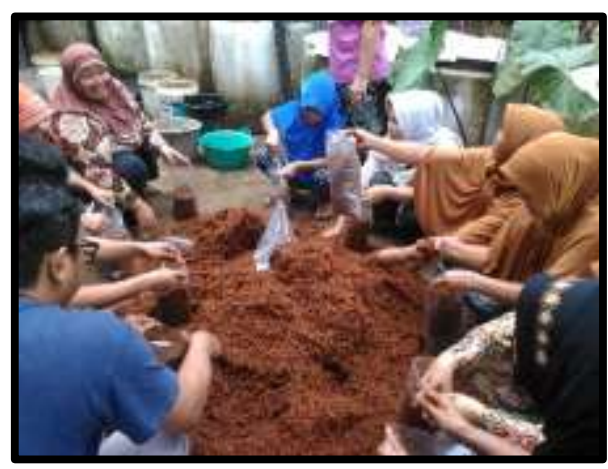

c.

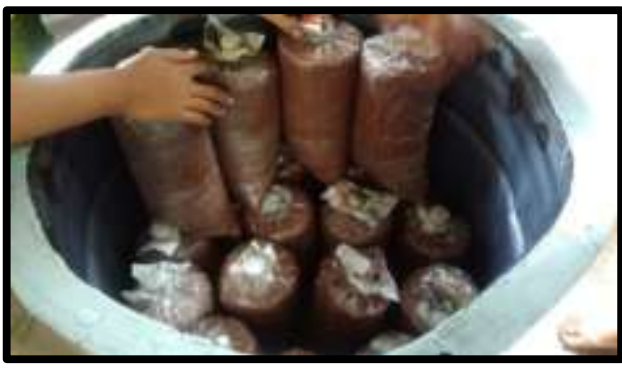

d.

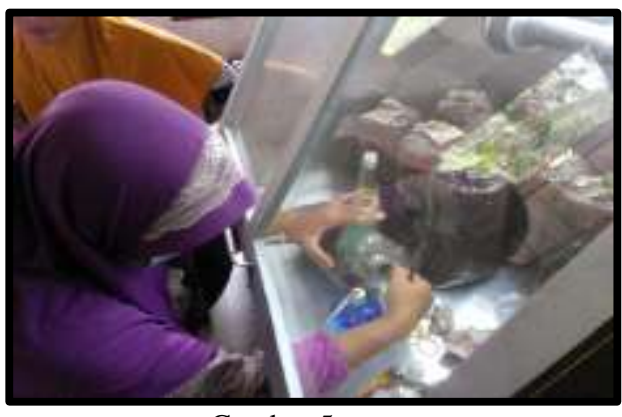

Gambar 5 .

Pelatihan dan praktik pembuatan baglog dan penggunaan autoklaf dan enkas

Tahapan terakhir dari PKM adalah pemantauan untuk melihat penggunaan fasilitas penunjang pada kedua mitra dan melihat hasil demonstrasi dan praktik yang telah dilakukan. Pemantauan yang dilakukan pada Kelompok Budidaya Jamur Sakinah diperoleh hasil bahwa terdapat baglog yang terkontaminasi jamur lain sehingga tidak bisa memproduksi jamur tiram. Kontaminasi ini dapat disebabkan oleh peserta saat menanam bibit F2 di enkas tidak dalam kondisi steril sepenuhnya. Hasil pemantauan ini telah dijelaskan kepada Ketua Kelompok Budidaya Jamur Sakinah dengan memberikan solusi berupa: 1) orang yang menanam bibit F2 di enkas sebaiknya hanya sedikit orang saja yang terampil untuk mengurangi kontaminasi dan usahakan kerja dalam keadaan steril serta tangan tidak keluar masuk enkas pada saat menanam bibit; 2) untuk pembuatan baglog selanjutnya, lebih baik menggunakan ukuran plastik yang lebih kecil untuk mempercepat pertumbuhan jamur dan mengurangi kontaminasi; dan 3) jumlah bibit yang ditanam ke dalam baglog diperbanyak untuk mempercepat pertumbuhan jamur ke seluruh baglog. 


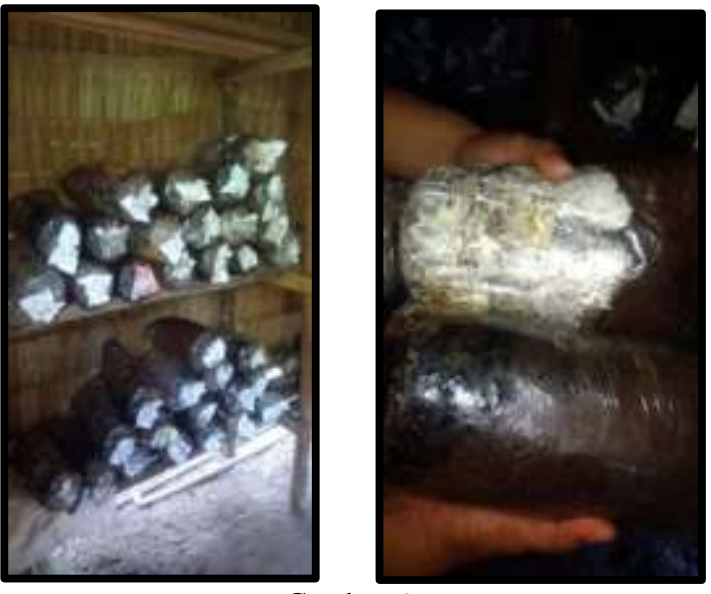

Gambar 6.

Hasil pemantauan baglog di kumbung Budidaya Jamur Sakinah

Pemantauan yang dilakukan pada PKK Desa Pinang Luar diperoleh hasil bahwa anggota PKK dalam membudidayakan hortikultura secara hidroponik masih terkendala pada perawatan. Perawatan yang dimaksud seperti jumlah nutrisi dalam bak nutrisi yang harus selalu dijaga kadar ppm-nya agar pertumbuhan tanaman dapat optimal. Akan tetapi, hal ini sudah diberikan solusi berupa pencatatan tabel kadar ppm yang diperlukan oleh masing-masing tanaman yang ditempel pada area dekat instalasi hidroponik sehingga anggota kelompok PKK Desa Pinang Luar yang bertugas dalam merawat tanaman dapat mengecek kadar ppm dalam bak nutrisi dan membandingkannya dengan tabel kadar ppm.

\section{KESIMPULAN}

Berdasarkan kegiatan yang telah dilaksanakan maka dapat disimpulkan bahwa Program Kemitraan Masyarakat telah tepat sasaran. Dimulai dari memfasilitasi peralatan autoklaf dan pendukungnya, enkas, instalasi hidroponik, dan kegiatan pelatihan penyemaian bibit untuk hidroponik serta kegiatan pelatihan pembuatan baglog. Peserta pelatihan juga memiliki antusiasme yang tinggi untuk memperoleh keterampilan dan pengetahuan tentang hidroponik.

\section{UCAPAN TERIMA KASIH}

Direktorat Riset dan Pengabdian Kepada Masyarakat, Direktorat Jenderal Penguatan Riset dan Pengembangan, Kementerian Riset, Teknologi, dan Pendidikan Tinggi

\section{REFERENSI}

Asegab M., 2011. Bisnis Pembibitan Jamur Tiram, Jamur Merang dan jamur Kuping. PT. Agro Media Pustaka. Jakarta.

Chang S.T., Miles P.G., 2004. Mushrooms: cultivation, nutritional value, medicinal effect, and environmental impact. CRC Press. Washington

Sinaga M.S., 2011. Budidaya Jamur Merang. Niaga Swadaya. Jakarta

Ulupi K.N., Hendrarti E.N, 2005. Sifat Fisik Bakso Daging Sapi dengan Jamur Tiram Putih (Pleurotus ostreatus) sebagai Campuran Bahan Dasar. Fakultas Peternakan Institut Pertanian Bogor, Bogor.

Wardani C., Suparti. 2014. Kadar Protein Jamur Tiram Putih (Pleurotus Ostreatus) pada Media Campuran Serbuk Gergaji, Ampas Tebu dan Arang Sekam. Universitas Muhammadiyah Surakarta 